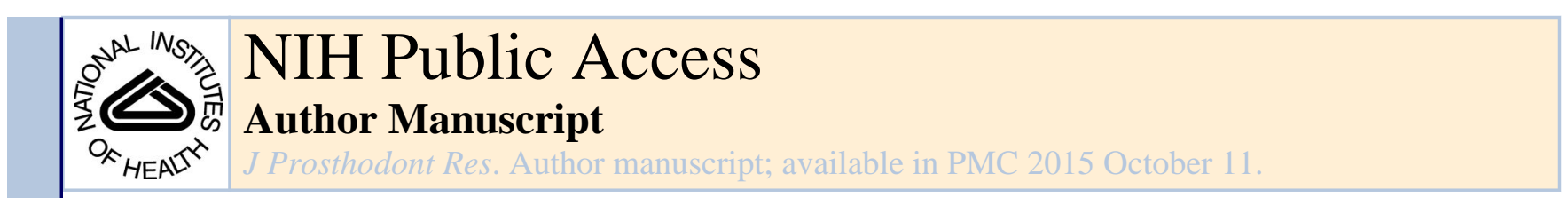

Published in final edited form as:

J Prosthodont Res. 2014 October ; 58(4): 193-207. doi:10.1016/j.jpor.2014.08.003.

\title{
Mechano-regulation of Collagen Biosynthesis in Periodontal Ligament
}

\author{
Masaru Kaku ${ }^{1,}$ and Mitsuo Yamauchi ${ }^{2}$ \\ ${ }^{1}$ Division of Bioprosthodontics, Niigata University Graduate School of Medical and Dental \\ Sciences, Niigata, Japan \\ ${ }^{2}$ North Carolina Oral Health Institute, University of North Carolina at Chapel Hill, NC, USA
}

\begin{abstract}
Purpose-Periodontal ligament (PDL) plays critical roles in the development and maintenance of periodontium such as tooth eruption and dissipation of masticatory force. The mechanical properties of PDL are mainly derived from fibrillar type I collagen, the most abundant extracellular component.
\end{abstract}

Study selection-The biosynthesis of type I collagen is a long, complex process including a number of intra- and extracellular post-translational modifications. The final modification step is the formation of covalent intra- and intermolecular cross-links that provide collagen fibrils with stability and connectivity.

Results-It is now clear that collagen post-translational modifications are regulated by groups of specific enzymes and associated molecules in a tissue-specific manner; and these modifications appear to change in response to mechanical force.

Conclusions-This review focuses on the effect of mechanical loading on collagen biosynthesis and fibrillogenesis in PDL with emphasis on the post-translational modifications of collagens, which is an important molecular aspect to understand in the field of prosthetic dentistry.

\section{Keywords}

Periodontal ligament; Mechanical loading; Collagen; Fibrillogenesis; Post-translational modification

\footnotetext{
(C) 2014 Japan Prosthodontic Society. Elsevier Ireland. All rights reserved

* Corresponding AuthorAddress 2-5274 Gakkochou-douri, Chuo-ku, Niigata 951-8514, Japan, TEL: +81-25-227-2897; FAX: +81-25-227-2899, kakum@dent.niigata-u.ac.jp.

Publisher's Disclaimer: This is a PDF file of an unedited manuscript that has been accepted for publication. As a service to our customers we are providing this early version of the manuscript. The manuscript will undergo copyediting, typesetting, and review of the resulting proof before it is published in its final citable form. Please note that during the production process errors may be discovered which could affect the content, and all legal disclaimers that apply to the journal pertain.

Conflict of interest statement

The authors certify that there are no conflicts of interest with any financial organization regarding the material discussed in this manuscript.
} 


\section{Introduction}

Periodontal ligament (PDL) is a specialized soft connective tissue that attaches the tooth to the alveolar bone socket. This fibrous tissue is very dynamic with high cellularity and vascularity, and plays critical roles in the development and maintenance of periodontium. These include: tooth support, regulation of tooth eruption, dissipation of masticatory forces, neurological feedback and orthodontic tooth movement. The mechanical properties of PDL are, thus, very important for these functions and they are mainly derived from the primary extracellular matrix protein; fibrillar type I collagen. One of the major characteristics of PDL collagen is its exceptionally high rate of turnover [1], which could be critical for tooth eruption and orthodontic tooth movement. One of the intriguing features of PDL is its ability to maintain the tissue without being mineralized despite the fact that it is connecting two specialized mineralized tissues, alveolar bone and cementum. Although this tissue is highly adaptive to external forces by temporarily changing the tissue space [2], the width remains relatively constant throughout its lifetime.

In daily prosthodontic practice, occlusion needs to be adjusted when a dental prosthesis is installed. The acceptable range of occlusal adjustment in natural teeth is generally considered to be $\sim 30 \mu \mathrm{m}$ because of the pressure displacement of PDL [3]. If the occlusal adjustment is performed inappropriately, it could cause widening of PDL space and increment of tooth mobility [4]. This clinical observation underscores the significance of optimum mechanical loading in the tissue maintenance of PDL. The expansion of PDL space and subsequent increase in tooth mobility are not only due to the expansion of PDL fibers, but also to the accelerated tissue turnover in response to mechanical loading [5]. Since fibrillar collagen is the predominant extracellular matrix (ECM) component of this tissue, it is important to understand how mechanical loading affects cells, subsequent collagen biosynthesis and tissue construction. Owing to recent advances in molecular and cellular biology and analytical technologies, it is now clear that collagen post-translational modifications are highly regulated by groups of specific enzymes, these modifications change in response to mechanical forces and ultimately affects collagen fibrillogenesis, stability and tissue mineralization [6-12]. This review focuses on the effects of mechanical loading on collagen biosynthesis and fibrillogenesis in PDL with emphasis on the posttranslational modification of collagens.

\section{Mechanical loading in PDL}

The PDL is subject to various mode of mechanical loading in different clinical circumstances. For instance, occlusal loading is the intermittent jiggling force and orthodontic tooth movement is the continuous static force. Thus, when the effect of mechanical loading on PDL is investigated, it is utmost important to carefully consider the loading conditions (e.g. mode, magnitude and duration) and interpret the data. Kang et al. reported that 2D and 3D cultured PDL-derived cells showed different gene expression profiles in response to similar mechanical loading [13]. This indicates that the culture environment could also influence on cellular response. To analyze the effect of mechanical loading on PDL-derived cells in vitro, a number of investigators have used commercially available loading apparatus, such as Flexcell (Flexcell International Co., Hillsborough, NC) 
[14-19], Strex (STREX Inc., Okayama, Japan) [20,21] and general laboratory centrifuge $[17,22,23]$, while others fabricated their own loading devices [24-27]. Since optimal mechanical loading varies depending on cell type, culture condition and loading mode, it is important to use well defined loading regimen with a thoroughly characterized loading apparatus. However, unfortunately, such characterization of loading apparatus has been often overlooked [28].

In animal studies, models such as excessive occlusal loading and orthodontic tooth movement are frequently used to analyze the effect of mechanical loading in PDL at the tissue level. Excessive occlusal loading condition can be created by bite-raising as reported by many groups [29-32]. However, with this model, loading conditions such as magnitude, frequency and profile of wave cannot be controlled. To overcome this limitation, a motorcontrolled device has recently been developed [33]. Using this device, the recruitment of TRAP-positive osteoclasts and the increment of RANKL/OPG ratio, which illustrates the osteoblast-mediated osteoclast recruitment, were confirmed in a magnitude- and timedependent manner. The orthodontic tooth movements have been simulated by inserting elastic rubber band between molars (Waldo method)[34] or by installing coil spring between incisor and molar [35]. In these models, the loading condition can be manipulated in a relatively well-controlled manner. Histological studies demonstrated that compression side of PDL showed destructive changes, while tension side revealed additive changes [35].

Though in vitro studies provide valuable insights as to how certain PDL-derived cells respond to the external stress at the molecular level, they cannot replicate the changes in vivo as the PDL consists of a variety of cells and extracellular matrices. Thus, in addition to an in vitro study, it is indispensable to characterize histological and biochemical changes of PDL in response to the mechanical loading by using a well characterized animal model.

\section{Collagens in PDL}

The major component of PDL is fibrillar collagens including types I, III and V, accounting for $\sim 75 \%, 20 \%$ and $5 \%$ of collagens, respectively [36,37]. In addition to the fibrillar collagens, non-fibrillar collagens such as types IV, VI, XII and XIV are also present as minor components in PDL [38,39] (Table 1). Microarray and expressed sequence (EST)-tag database studies have indicated that more collagen types, such as type II, XI, XV and XVI, are present in PDL [40,41]. Fibrillar collagens are the scaffold that provides tissue with form, connectivity and tensile strength; thus, genetic disorders in these collagens can result in severe connective tissue-related diseases [42]. While the tensile strength of PDL is provided primarily by fibrillar collagens, resistance against compressive forces in this tissue is likely carried out by water, hyaluronic acid and various proteoglycans [43]. The diameter of PDL collagen fibrils is relatively smaller than those of other connective tissues, likely due to the high rate of collagen turnover [1] and the presence of non-collagenous components that regulate collagen fibrillogenesis [44]. These fibrillar collagens, i.e. principal fibers in PDL, are not mineralized and appear to be highly glycosylated. On the other hand, fibrils of the Sharpey's fibers that are embedded in bone and cementum have a larger diameter and are partially mineralized. The site-specific composition and structural characteristics of 
collagens and non-collagenous components could be an important factor for the function of PDL, and to prevent or facilitate proper mineralization.

\section{Type I collagen}

Type I collagen is the most abundant type of collagen among the collagen superfamily, comprising 29 members encoded by at least 44 genes, and is the structural basis for the form and mechanical properties in most tissues and organs. It is a heterotrimeric molecule composed of two a 1 chains and one a 2 chain, approximately $300 \mathrm{~nm}$ in length and $1.5 \mathrm{~nm}$ in thickness. The biosynthesis of type I collagen is a long, complex process that includes gene transcription, post-translational modifications of proa chains, formation of a triplehelical procollagen molecule, secretion to ECM, enzymatic processing to form a collagen molecule, self-assembly into a fibril and stabilization by covalent intra- and intermolecular cross-linking (for details, see recent reviews [6,45,46]) (Fig. 1). Intra- and extracellular posttranslational modifications during biosynthesis are critical for the structural function of collagen fibrils. A number of enzymes, their binding molecules and molecular chaperones are involved in such modifications and most of these enzymes are collagen specific.

\section{4-1. Epigenetic control of type I collagen}

One of the first molecular mechanisms that regulate the gene expression of collagens is epigenetic modification, modulating transcription factor accessibility in an inherited manner without changing genomic DNA. The main epigenetic mechanisms of gene regulation are DNA methylation and histone modification [47]. Several studies have suggested that methylation of the cytosine residue at the $\mathrm{CpG}$ sequence in the promoter region suppresses gene expression, and that demethylation re-activates gene expression. It has reported that the age-associated decrease in type I collagen production in PDL cells is partly due to hypermethylation in the promoter region of the COL1A1 gene [48,49]. Arnsdolf et al. reported that 3 hours of oscillatory fluid flow reduced the DNA methylation of Collal gene promoter and associated increase in the expression of Collal gene on mouse bone marrow stromal cells [50]. It is thus possible that mechanical loading regulates the gene expression of type I collagen in PDL in an epigenetic manner.

\section{4-2. Expression of type I collagen genes}

Numerous studies have demonstrated that the gene expression of type I collagen (i.e., COL1A1 \& COL1A2 in human and Colla1 \& Colla2 in mice) are altered by mechanical loading in PDL-derived cells; however, the results are not consistent. Many have reported that the gene expression is up-regulated with mechanical loading [16,17,22,25,51], while others have reported it is unchanged or decreased [14,20,26,27,52]. Such inconsistent outcomes are likely due to differences in loading regimen (i.e., compression vs. tension, cyclic vs. static, frequency, duration.) and culture conditions. Comparative studies have been performed in order to analyze the effects of different loading conditions on the gene expression of type I collagen in PDL. A recent study by Chen et al. showed that $3 \%$ cyclic stretching increased the gene expression of COL1Al but decreased by $10 \%$ cyclic stretching on human PDL-derived cells [19]. Another study, by He et al. compared the effect of cyclic equibiaxial tension and compressive forces on the expression of type I collagen by using 
human PDL-derived cells [24]. In this study, they reported that ten hours of $10 \%$ tension force increased the expression of COLIAl gene, however, same magnitude of compressive force decreased the expression of COL1Al gene. These data suggest that the effect of mechanical loading on type I collagen gene expression in PDL cells is magnitude-, durationand mode-dependent.

\section{4-3. Post-translational modifications of type I collagen}

It has been reported that there is a discrepancy between the expression of genes encoding type I collagen (i.e., COL1A1 and COL1A2) and the production of type I collagen protein [53] (Fig. 2). Such discrepancies occur, in part, due to the complex biosynthesis process [46] including the sequential and multiple processes of post-translational modifications necessary for proper proa chain folding into triple helix, fibrillogenesis and stabilization of fibrils. Thus, to characterize the response of PDL cells to mechanical loading, it is necessary to analyze not only the gene expression of type I collagen itself, but also the expression of collagen modifying enzymes, their associated molecules and molecular chaperons.

4-3-1. Prolyl Hydroxylases-The majority of proline (Pro) hydroxylation of collagen $(\sim 99 \%)$ is in the form of 4-hydroxyproline (4-Hyp). It occurs in the sequence of -X-Pro-Gly (glycine)- being catalyzed by prolyl-4-hydroxylase $(\mathrm{P} 4 \mathrm{H})$. This modification is critical for the stabilization of triple helix conformation [54]. A very small number of Pro hydroxylation $(\sim 1 \%)$ occurs in form of 3-Hyp at Pro in the sequence of -Pro-4Hyp-Gly-catalyzed by the collagen prolyl 3-hydroxylation complex $(\mathrm{P} 3 \mathrm{H})$. In type I collagen, the major target residues for P3H are a1-Pro986 and a2-Pro707 [55,56]. Recently, much attention has been paid on this particular modification as defects in the genes encoding the components of the $\mathrm{P} 3 \mathrm{H}$ complex cause recessive osteogenesis imperfect [55]. The complex is composed of prolyl 3hydroxylase 1, cartilage-associated protein and cyclophilin B, residing in the endoplasmic reticulum. It is still not clear, however, how the lack of 3-hydroxylation in Pro causes such severe connective tissue phenotypes. Possibly, defects in this complex may also affect proper Lys modifications as some of them interact with lysyl hydroxylases [57], which could lead to defective collagen cross-linking [58]. The extent of 3-Hyp in PDL type I collagen is unknown. The expression of P4H in PDL cells was reported previously [59], however; there have been no reports on the expression of $\mathrm{P} 3 \mathrm{H}$, and the mechanoresponsiveness of these genes in PDL.

4-3-2. Lysyl Hydroxylases-Specific lysine (Lys) residues of collagen can also be hydroxylated in the form of 5-hydroxylysine (Hyl). This modification is catalyzed by lysyl hydroxylases (LHs) encoded by procollagen-lysine, 2-oxoglutarate 5-dioxygenase (PLOD) genes. Lys hydroxylation occurs both in the helical-, and C- and N-telopeptide domains of type I collagen molecule. In the helical domain, it if formed in the sequence of -X-Lys-Gly (glycine)-, and in the telopeptide domains in -X-Lys-Ala (alanine)- and -X-Lys-Ser (serine) sequences. To date, three isoforms of LHs have been identified (LH1-3) and partially characterized.

The substrate specificities of these isoforms in vivo are still not clearly established; however, substantial evidence indicate that LH1 primarily hydroxylates Lys residues in the helical 
domains of fibrillar and non-fibrillar collagens [60]. For LH2, two alternatively spliced isoforms were identified, i.e. LH2a or LH2 (short) and LH2b or LH2 (long), respectively. The latter (LH2b) includes an additional 21 amino acids (exon 13A) and appears to be the major form of LH2 in most tissues [61]. Several studies indicate that LH2 (LH2b) functions as a telopeptidyl LH [10,62-64]. LH3 is a multifunctional enzyme possessing LH, GT (hydroxylysyl galactosyltransferase) and GGT (galactosylhydroxylysyl glucosytransferase) activities [65]. However, for type I collagen, the main function of LH3 appears to be GGT not LH or GT [7,8](see section 4-3-3 for GTs and GGTs).

It has also been reported that various factors influence the expression of LHs and subsequent Lys hydroxylation, including growth factors [66] and vitamin D [67], as well as mechanical loading $[11,68,69]$. Saito et al. reported that twenty-gram of gravitational force increased the gene expression of $L H 2$ in an osteoblastic cell culture, while simulated zero-gravity increased the gene expression of $L H 1$ [69]. In PDL-derived cells, it was reported that the static compressive force induces the expression of $L H 2$ [70]. We also confirmed that $L H 2$ responded to both static and cyclic compressive force in human PDL-derived cells and the PDL of excessively occluded molars in rat (Fig. 3, Kaku M, unpublished data). The $L H 2$ is a causative gene in Bruck syndrome, which is characterized by osteoporosis, joint contracture at birth, fragile bones and short stature, and exhibits under hydroxylation of Lys residues in telopeptides of type I collagen in bone; however, cartilage and ligament collagen shows normal hydroxylation of telopeptidyl Lys and normal patterns of cross-linking [64,71]. These results suggest that tissue-specific changes in Lys hydroxylation in type I collagen by mechanical loading may contribute to the tissue-specific collagen cross-linking pattern (see section 4-3-6).

4-3-3. Molecular Chaperones and Peptidyl-proryl cis-trans isomerases-Heat shock protein 47 (HSP47) is a collagen-specific molecular chaperone that inhibits collagen aggregation in the endoplasmic reticulum by binding a proa chains, facilitating the correct folding into the triple helix [72,73]. Transgenic mouse studies revealed that mutations in HSP47 cause collagen-related genetic disorders such as osteogenesis imperfecta [74,75]. As the nature of heat shock protein, HSP47 is responsive to various stimuli, including heat stress, growth factors and mechanical loading, HSP47 rapidly detects mechanical loading and affects type I collagen fibrillogenesis [76,77].

Secreted Protein Acidic and Rich in Cysteine (SPARC)/osteonectin was originally identified as a collagen-binding glycoprotein, playing an extracellular role in collagen fibrogenesis [78]. SPARC is preferentially expressed in tissues with a high rate of collagen turnover, including PDL. SPARC-null mice demonstrated that the number of cells and collagen volume were markedly diminished in PDL, indicating crucial roles in PDL homeostasis [79]. Recent studies have shown that secreted SPARCs are internalized to cells and act intracellulary as molecular chaperones in concert with HSP47 [80-82]. Since both SPARC and HSP47 are known to be expressed in response to various stresses [82], these molecules may have some roles in the collagen fibrillogenesis in PDL in response to mechanical loading.

J Prosthodont Res. Author manuscript; available in PMC 2015 October 11. 
Proline isomerization is the rate-limiting step during triple helical formation of procollagen and this is catalyzed by a group of isomerases, Peptidylprolylisomerase (PPIase). Among seven PPIases residing in rough endoplasmic reticulum, three of them have been shown to be involved in procollagen biosynthesis, i.e. cyclophilin B, FK506-binding protein (FKBP) 65 and 22 [57]. The absence of these proteins lead to a recessive form of osteogenesis imperfecta or kyphoscoliotic type of Ehlers-Danlos Syndrome (type VI). PPIases form complexes with many collagen related proteins and play important roles in the collagen fibrillogenesis, however, to date, there are no reports regarding the expression and mechanoresponses of PPIases in PDL cells.

4-3-4. Glycosyl transferases-Type I collagen glycosylation is $O$-linked glycosylation occurring at specific Hyl residues in the helical domain of the molecule, thus, Lys hydroxylation catalyzed by LHs is prerequisite for this modification. Structurally, galactose is attached to the hydroxyl group of Hyl by a $\beta$-glycosidic bond, while glucose is linked by an a-glycosidic bond to $\mathrm{C}-2$ of the galactose [6]. These modifications are catalyzed by two groups of collagen glycosyltransferases i.e. hydroxylysyl galactosyltransferase (GT) and galactosylhydroxylysyl glucosyltransferase (GGT) (see section 4-3-2) producing galactosylhydroxylysine (G-Hyl) and glucosylgalactosylhydroxylysine (GG-Hyl), respectively [6]. With regard to GT, GLT25D1 and GLD25D2 have been identified [83]. The Gld25dl showed broad expression in several tissues, while Glt $25 d 2$ was expressed in only a limited number of cell types, suggesting that GLT25D1 is the major isoform [83]. As for GGT, recent studies have indicated that LH3 is the major GGT enzyme for type I collagen $[7,8,83]$. The level of glycosylation differs among different types of collagen and, even within the same type of collagen, it differs from tissue to tissue. It has been reported that collagen glycosylation may contribute to structural and biological functions, such as control of collagen fibrillogenesis [84-87], collagen cross-linking [37,88,89] and collagencell interaction [90,91]. It has been reported that altered collagen glycosylation is associated with bone disorders, such as osteogenesis imperfecta [92-94], postmenopausal osteoporosis $[95,96]$ and osteosarcoma, osteofibrous dysplasia [97], suggesting the significant roles of collagen glycosylation in mineralization. The most predominant glycosylated site of type I collagen, a1/2 Hyl-87, is one of the major helical cross-linking sites [98,99]. A recent study demonstrated that the glycosylation pattern is significantly different between immature and mature cross-links in types I and II collagen [100]. This, together with a report by Srichiolpech et al. suggest that di-glycosylation negatively controls the process of cross-link maturation [7]. It is interesting to note that, in PDL type I collagen, the cross-links involving a1/2 Hyl-87 PDL are mostly di-glycosylation forms, and they are predominantly immature cross-links [37]. This specific glycosylation pattern in PDL type I collagen may be associated with the smaller diameter of PDL collagen fibrils and possibly contribute to maintenance of non-mineralized state of this tissue.

4-3-5. Lysyl Oxidases-Once a triple-helical procollagen is formed, the molecules are packaged and secreted to the extracellular matrix (ECM) through the Golgi apparatus. In the ECM, the $\mathrm{N}$ - and C-terminal propeptide extensions are cleaved by procollagen proteinases generating a mature type I collagen molecule. These molecules are then self-assemble to form a fibril; a process called "fibrillogenesis", and stabilized by the formation of covalent 
intra- and intermolecular cross-linking (see section 4-3-6). In order to initiate cross-linking, the telopeptidyl Lys or Hyl need to be converted to the respective aldehyde forms, Lys ${ }^{\text {ald }}$ and $\mathrm{Hyl}^{\text {ald }}$, by oxidative deamination catalyzed by an enzyme, lysyl oxidase (LOX). Once aldehyde is formed, the rest of the condensation reactions are spontaneous. These aldehydes spontaneously react with other aldehydes or $\varepsilon$-amino groups of unmodified Lys and Hyl residues to form a variety of intra- and intermolecular cross-links, which are critical for the formation of mechanically functional collagen fibrils. Together with the LOX, several isoforms of LOX, i.e. LOX-like proteins (LOXL1-4) have been identified. Recent findings revealed that LOX and LOXL proteins could be involved in various molecular functions other than collagen and elastin cross-linking, including chemotactic responses, tumor suppression and controlling growth factor activity. [101,102]. Increases in LOX expression in response to mechanical loading have been reported in bone marrow stromal cells [103], dermal fibroblast [104] and PDL-derived cells [19]. LOX is synthesized as proLOX and is processed by BMP1/Tolloid-like proteinases, the same proteinases that cleave the $\mathrm{C}$ propeptide of type I procollagen, to form mature and active LOX [105]. It has been reported that the BMP1-mediated proteolytic activation of LOX is coordinately regulated by periostin which is a secretory matricellular protein, expressed in collagen-rich fibrous connective tissues, including PDL [106,107]. The PDL in periostin-null mice exhibits irregular collagenous fibrils and changes in the organization of major ECM proteins such as type I collagen, fibronectin and tenascin-C [108-110]. Orthodontic tooth movement increased the expression of periostin in wild type mice but resulted in the expansion of PDL width with the decreased immunolocalization of cathepsin K, MMP1 and MMP2 in periostin null-mice [109]. These results suggest that proteolytic regulation of LOX activity could be different in PDL.

4-3-6. Collagen cross-links-The final step of collagen biosynthesis is the formation of covalent intra- and intermolecular cross-links (for a review, see $[6,111,112]$ ). The importance of collagen cross-linking cannot be over-emphasized, as it is the molecular basis for the tissue stability. As described above, the formation of $\mathrm{Lys}^{\text {ald }}$ or Hyl ${ }^{\text {ald }}$ in the telopeptides by the action of LOX initiates the cross-linking process, and the rest of the condensation reactions are non-enzymatic. Many factors determine cross-linking pattern including: the initial aldehyde form (Lys ${ }^{\text {ald }}$ or Hyl ${ }^{\text {ald }}$ ), extent of hydroxylation of the juxtaposed Lys residues on a neighboring molecule, glycosylation of Hyl involved in the reaction and microenvironment such as mechanical loading, mineralization and turnover rate [6]. Since these modifications and microenvironment vary among different cell types and tissues, collagen cross-linking pattern is highly tissue-specific and reflects tissue's physiological state and function. For instance, it has been reported that PDL type I collagen possesses abundant amounts of immature cross-links (three major reducible cross-links) with only small amounts of mature, stable cross-links [37]. Such pattern would allow the tissue to have high tensile strength, but at the same time to be readily turned over. Interestingly the bi-functional immature cross-links in PDL are mostly di-glycosylated which may also contribute to the negative control of collagen maturation. Though what precisely controls this specific cross-linking pattern in PDL is not clearly understood, specific microenvironment including constant mechanical loading would certainly be a contributing factor. 
To the best of our knowledge, only one paper reported the direct measurement of the changes in collagen cross-linking in response to mechanical loading in PDL. Plecash et al. analyzed the composition of two immature, bi-functional cross-links in the occluded and non-occluded PDL of dogs (2, 4 and 6 weeks) and observed no significant difference among the different groups, concluding that a high rate of collagen turnover in PDL is intrinsic but not as a result of external or eruptive force [113]. However, the data need to be interpreted carefully as the number of analysis is very limited, i.e. single analysis per time point, use of a different type of dog at each time point, and lack of quantitative analysis for other crosslinks in PDL. In another study, it has been reported that the bovine PDL exhibits no significant changes in the quantities of the two immature, bi-functional collagen cross-links during development and maturation [114]. But similar limitations may apply to this study. Further studies are needed to elucidate the effect of mechanical loading on the collagen cross-linking in PDL.

Effect of mechanical loading on the collagen cross-linking in bone has been relatively well investigated. Shiiba et al. reported that, employing a rat tail suspension model, mechanical unloading significantly changed the composition of collagen cross-links likely due to an increase in Lys hydroxylation [11,68]. Saito et al. reported that hyper-gravitational force enhanced not only the total reducible and non-reducible cross-link contents and the rate of cross-link maturation in an osteoblast culture system [69].

\section{Other types of collagen}

Type III collagen is a fibrillar collagen comprising three a 1 chains and is typically colocalized with type I collagen within the same fibril [115]. The PDL contains a considerable amount of type III collagen ( 20\%) as compared with bone ( 1\%), cementum ( $\sim 5 \%)$ and gingiva $(\sim 10 \%)$, however, the functional significance of the type III collagen in PDL is poorly understood. This amount of type III collagen is relatively high for mature connective tissue and is more characteristic of fetal connective tissue. Deficiency in Col3al gene, which encodes type III collagen, in mice results in shorter lifespan due to the rupture of major blood vessels; therefore, type III collagen is considered to be essential for normal type I collagen fibrillogenesis [116]. In humans, patients with type IV Ehlers-Danlos syndrome, which shows fragile and inextensible connective tissues, lack the expression of type III collagen [117]. Increases in type III collagen were observed in early phases of wound healing and were eventually replaced with type I collagen [118]. In particular, in the early healing process, Sharpey's fiber-like structure in the tendon-bone interface express type III collagen [119-121]. Furthermore, increases in type III collagen expression in response to mechanical loading has been reported in dermal fibroblasts , mesenchymal stem cells [122], anterior crucial ligament cells [123] and medial collateral ligament [124]. Expression of type III collagen in PDL-derived cells is reported to increase at lower-magnitude of loadings, but decrease at higher-magnitude of loadings [19]. The abundance of type III collagen in PDL may therefore be related to a key function in PDL, such as the integrity of the PDL-bone and -cementum interface, or is a consequence of the PDL's rapid turnover [1].

Type XII collagen is a member of fibril-associated collagens with interrupted triple helices (FACIT), originally identified in bovine PDL [125]. The type XII collagen is a homo-trimer 
of a 1 chains and each chain has two triple helical collagenous domains (COL1 and 2) with three separate noncollagenous domains (NC1-3). The collagenous domains, which comprise only $\sim 7.7 \%$ of the molecule, have an affinity for fibrillar collagen (i.e., type I and III collagen in PDL) $[126,127]$ and non-triple-helical domains provide sites for interaction with other extracellular matrix such as fibromodulin, decorin and tenascin-XB [128,129]. Type XII collagen has been shown to be mainly expressed in the dense collagenous connective tissues of tendons, ligaments, dermis, cornea blood vessel walls [130] and to be distributed in well-organized mature fibrils [131]. In PDL, type XII collagen is expressed in a mature/ functional stage, as compared with developing stages, while the expression of type I collagen decreases with maturity $[39,132]$. Tzortzaki et al. speculated that type XII collagen transiently stabilizes the type I collagen fibrils until LOX catalyzes the inter-molecular collagen cross-linking [133]. Type XII collagen-expressing cells were localized on the alveolar bone side of PDL, where mature collagenous fibers are accumulated in comparison with the cementum side [134]. A transgenic mouse line carrying a dominant interference mutation of the type XII collagen gene demonstrated disorganized collagen fibers associated with internal porosity in PDL [135]. Type XII collagen is mainly present in two splicing variants, a large form (XIIA), and a small form (XIIB) [136,137], and these are generally coexpressed in a mutually exclusive manner. Only the XIIA isoform contains sulfated glycosaminoglycans in an NC3 domain and is therefore a proteoglycan. XIIA is generally found in the developing tissue, whereas type XIIB is expressed in the mature tissue; therefore, it is anticipated that adult PDL predominantly contains XIIB [138].

The expression and alternative splicing of type XII collagen is known to be regulated by mechanical loading in various cell, such as fibroblasts [139,140], trabecular meshwork cells [141], vascular endothelial cells [142] and osteoblasts [143], as well as PDL-derived cells $[20,138]$. The promoter activity of type XII collagen is directly stimulated by mechanical loading, thus suggesting the conservation of a stress-response element $[143,144]$. Upregulation of type XII collagen occurs during orthodontic tooth movement in the cells on the tension side, where there is an abundance of mature collagen fibers [138]. Taken together, these observations suggest that type XII collagen is responsible for the organization of collagenous fibers in response to mechanical loading in mature PDL.

\section{Small leucine-rich proteoglycans (SLRPs)}

Small leucine-rich proteoglycans (SLRPs) belong to the LRR superfamily of proteins, constituting a network of signal regulation mostly at the extracellular level $[145,146])$. SLRPs regulate collagen fibrillogenesis by binding to specific sites of collagen molecules. Several SLRP family members have been identified in PDL $[147,148]$. The role of SLRPs in collagen fibrillogenesis and subsequent tissue conformation have been extensively studied in either single- or double-mutant transgenic mice [149]. Targeted deletion of decorin, fibromodulin, lumican or both lumican and fibromodulin resulted in the formation of abnormal collagen fibrils and fiber organization was evident in the PDL [148]. The decorinnull mice displayed larger diameter collagen fibers with randomly arranged orientation in PDL. In addition to collagen phenotype, the number of fibroblasts in the PDL is doubled in decorin-deficient mice, indicating hyper-cellularity due to increased proliferation in the 
absence of inhibitory signals from decorin [150,151]. Some SLRPs, (e.g., decorin and biglycan) are reported to be responsive to mechanical loading in PDL-derived cells $[51,152]$.

Another SLRP member, asporin, is predominantly expressed in PDL. Unlike other SLRP family members, asporin does not possess a glycosaminoglycan chain, thus, not a proteoglycan. Asporin is associated with various bone and joint diseases, including osteoarthritis, rheumatoid arthritis and lumbar disc disease, and it binds to collagens to complement decorin, and it appears to regulate collagen fibrillogenesis and biomineralization [153]. Asporin also binds to TGF-beta [154] and BMP-2 [155] and it is thought to be negatively regulating their activities to prevent non-physiological mineralization of PDL such as in ankylosis.

\section{Future Directions}

The biosynthesis of type I collagen is a complex process, involving several post-translational modifications. These modifications are functionally important and are in part regulated by mechanical loading at different stages (Summarized in Fig. 4). Thus, with the tissue's exposure to constant mechanical loading, it is likely that PDL collagen has unique molecular and structural characteristics that have been just partially elucidated.

To analyze the changes in post-translational modifications of collagen, high performance liquid chromatography (HPLC)-based biochemical analysis have been the gold standard $[37,156]$. By the HPLC-based analysis, collagen contents and the extent of post-translational modifications are determined in a quantitative manner [156]. Recently, liquid chromatography-tandem mass spectrometry (LC/MC) has become a powerful tool to characterize the post-translational modifications of collagens in a molecular site-specific and semi-quantitative fashion [58,157]. Data obtained from such analytical methods in various experimental models would provide valuable insights into the biochemical characteristics of PDL collagen, its response to mechanical loading and their biological significance.

However, due to the thin, small, membrane-like structure of PDL, it is still technically challenging to collect sufficient amount of tissue samples for biochemical analysis. To characterize the spatial differences of collagen organization and maturation in PDL, polarized light-based birefringence analysis have been used [158]. More recently, microscope-equipped vibrational spectroscopy, including Fourier transform infrared (FTIR) and Raman techniques, has been developed to characterize the chemical composition and bonding microenvironment of the tissue constituents $[159,160]$. FTIR analysis could be used to characterize the extent of collagen cross-link maturation at the tissue level [161], thus, utilization of such imaging techniques could be useful to characterize the effects of mechanical loading on the collagen maturation, fibrillogenesis and matrix organization of PDL in appropriate animal models.

In order to identify the mechano-responsive molecules in PDL, microarray technology has been utilized over the last decade; however, the data have been inconsistent $[13,20,40,51,52,70,162-168]$ likely due to the differences in culture conditions, loading regimens and the nature of primary cells used. It should be kept in mind that PDL harbors many cell types, e.g., fibroblasts, osteoblasts, cementoblasts, endothelial cells, epithelial cell 
rests of Malassez and osteoclasts. Furthermore, fibroblasts, the principal cells in PDL, can be further classified into sub-populations with different functional characteristics [169]. It is evident that, significant number of peri-vascular stem cells are present in PDL [170,171]. These cells can, in theory, differentiate into any types of cells in PDL, however, the factors that control the fate of PDL stem cells are still poorly understood. Possibly, site-specific mechanical loading and microenvironment of stem cells such as the mechanical property of ECM are contributing factors [172,173].

As summarized in this review, mechanical loading regulates the collagen biosynthesis in a tissue specific manner that could directly affect the mechanical function of PDL. The expression of collagen post-translational enzymes and their associated molecules (Table 2), and the response of these molecules to mechanical loading as a function of anatomical location in PDL will be an important subject to study in the field of prosthetic dentistry.

\section{Acknowledgments}

This review article was written as a project of the Journal of Prosthodontic Research (JPR) Editorial Committee with the support of the Japan Prosthodontic Society (JPS). The authors thank Prof. Katsumi Uoshima, the Chair of the Div. of Bioprosthodontics, Niigata University for his encouragement and valuable comments. Studies described in this review were supported by a Grant-in-Aid for Young Scientists from the Japan Society for the Promotion of Science (MK, 24792068) and by National Institute of Health grant (MY, AR060978).

\section{Abbreviations}

$\begin{array}{ll}\text { PDL } & \text { Periodontal ligament } \\ \text { ECM } & \text { Extracellular matrix } \\ \text { Pro } & \text { Proline } \\ \text { P4H } & \text { Prolyl-4-hydroxylase } \\ \text { P3H } & \text { Prolyl-3-hydroxylase } \\ \text { Lys } & \text { Lysine } \\ \text { LH } & \text { Lysyl hydroxylase } \\ \text { GGT } & \text { Galactosylhydroxylysine-glucosyl transferase } \\ \text { GT } & \text { Hydroxylysyl galactosyl transferase } \\ \text { LOX } & \text { Lysyl oxidase } \\ \text { FACIT } & \text { Fibril-associated collagens with interrupted triple helices } \\ \text { SLRPs } & \text { Small leucine-rich proteoglycans } \\ \text { HPLC } & \text { High performance liquid chromatography } \\ \text { LC/MC } & \text { Liquid chromatography-tandem mass spectrometry } \\ \text { FTIR } & \text { Fourier transform infrared }\end{array}$




\section{References}

1. Sodek J. A comparison of the rates of synthesis and turnover of collagen and non-collagen proteins in adult rat periodontal tissues and skin using a microassay. Arch Oral Biol. 1977; 22:655-65. [PubMed: 272138]

2. Wank GS, Kroll YJ. Occlusal trauma. An evaluation of its relationship to periodontal prostheses. Dental clinics of North America. 1981; 25:511-32. [PubMed: 7021239]

3. Muhlemann HR. Periodontometry, a method for measuring tooth mobility. Oral Surg Oral Med Oral Pathol. 1951; 4:1220-33. [PubMed: 14882794]

4. Lindhe, J.; Lang, N.; Karring, T. Clinical Periodontology and Implant Dentistry. 5th. WileyBlackwell; 2008.

5. McCulloch CA, Lekic P, McKee MD. Role of physical forces in regulating the form and function of the periodontal ligament. Periodontol 2000. 2000; 24:56-72. [PubMed: 11276873]

6. Yamauchi M, Sricholpech M. Lysine post-translational modifications of collagen. Essays Biochem. 2012; 52:113-33. [PubMed: 22708567]

7. Sricholpech M, Perdivara I, Yokoyama M, et al. Lysyl hydroxylase 3-mediated glucosylation in type I collagen: molecular loci and biological significance. The Journal of biological chemistry. 2012; 287:22998-3009. [PubMed: 22573318]

8. Sricholpech M, Perdivara I, Nagaoka H, Yokoyama M, Tomer KB, Yamauchi M. Lysyl hydroxylase 3 glucosylates galactosylhydroxylysine residues in type I collagen in osteoblast culture. The Journal of biological chemistry. 2011; 286:8846-56. [PubMed: 21220425]

9. Pornprasertsuk S, Duarte WR, Mochida Y, Yamauchi M. Overexpression of lysyl hydroxylase-2b leads to defective collagen fibrillogenesis and matrix mineralization. J Bone Miner Res. 2005; 20:81-7. [PubMed: 15619673]

10. Pornprasertsuk S, Duarte WR, Mochida Y, Yamauchi M. Lysyl hydroxylase-2b directs collagen cross-linking pathways in MC3T3-E1 cells. J Bone Miner Res. 2004; 19:1349-55. [PubMed: 15231023]

11. Shiiba M, Arnaud SB, Tanzawa H, Kitamura E, Yamauchi M. Regional alterations of type I collagen in rat tibia induced by skeletal unloading. J Bone Miner Res. 2002; 17:1639-45. [PubMed: 12211434]

12. Eyre DR, Weis MA. Bone collagen: new clues to its mineralization mechanism from recessive osteogenesis imperfecta. Calcif Tissue Int. 2013; 93:338-47. [PubMed: 23508630]

13. Kang KL, Lee SW, Ahn YS, Kim SH, Kang YG. Bioinformatic analysis of responsive genes in two-dimension and three-dimension cultured human periodontal ligament cells subjected to compressive stress. Journal of periodontal research. 2013; 48:87-97. [PubMed: 22823265]

14. Uno K, Abiko Y, Takita H, et al. Effects of mechanical stress on the eryression of type XII collagen mRNA in human periodontal ligament cells. Journal of hard tissue biology. 2001; 10:116-22.

15. Kook SH, Lee JC. Tensile force inhibits the proliferation of human periodontal ligament fibroblasts through Ras-p38 MAPK up-regulation. J Cell Physiol. 2012; 227:1098-106. [PubMed: 21567397]

16. Kook SH, Jang YS, Lee JC. Involvement of JNK-AP-1 and ERK-NF-kappaB signaling in tensionstimulated expression of type I collagen and MMP-1 in human periodontal ligament fibroblasts. $\mathrm{J}$ Appl Physiol (1985). 2011; 111:1575-83. [PubMed: 21757573]

17. Kook SH, Hwang JM, Park JS, et al. Mechanical force induces type I collagen expression in human periodontal ligament fibroblasts through activation of ERK/JNK and AP-1. Journal of cellular biochemistry. 2009; 106:1060-7. [PubMed: 19206162]

18. Enokiya Y, Hashimoto S, Muramatsu T, et al. Effect of stretching stress on gene transcription related to early-phase differentiation in rat periodontal ligament cells. Bull Tokyo Dent Coll. 2010; 51:129-37. [PubMed: 20877159]

19. Chen YJ, Jeng JH, Chang HH, Huang MY, Tsai FF, Yao CC. Differential regulation of collagen, lysyl oxidase and MMP-2 in human periodontal ligament cells by low- and high-level mechanical stretching. Journal of periodontal research. 2013; 48:466-74. [PubMed: 23190051] 
20. Nemoto T, Kajiya H, Tsuzuki T, Takahashi Y, Okabe K. Differential induction of collagens by mechanical stress in human periodontal ligament cells. Arch Oral Biol. 2010; 55:981-7. [PubMed: 20832771]

21. Takano M, Yamaguchi M, Nakajima R, Fujita S, Kojima T, Kasai K. Effects of relaxin on collagen type I released by stretched human periodontal ligament cells. Orthod Craniofac Res. 2009; 12:282-8. [PubMed: 19840280]

22. Hacopian N, Nik TH, Ghahremani MH, Rahimi HR, Ostad SN. Effects of continuous and interrupted forces on gene transcription in periodontal ligament cells in vitro. Acta Med Iran. 2011; 49:643-9. [PubMed: 22071638]

23. Redlich M, Roos H, Reichenberg E, et al. The effect of centrifugal force on mRNA levels of collagenase, collagen type-I, tissue inhibitors of metalloproteinases and beta-actin in cultured human periodontal ligament fibroblasts. Journal of periodontal research. 2004; 39:27-32. [PubMed: 14687224]

24. He Y, Macarak EJ, Korostoff JM, Howard PS. Compression and tension: differential effects on matrix accumulation by periodontal ligament fibroblasts in vitro. Connect Tissue Res. 2004; 45:28-39. [PubMed: 15203938]

25. Howard PS, Kucich U, Taliwal R, Korostoff JM. Mechanical forces alter extracellular matrix synthesis by human periodontal ligament fibroblasts. Journal of periodontal research. 1998; 33:500-8. [PubMed: 9879524]

26. Ziegler N, Alonso A, Steinberg T, et al. Mechano-transduction in periodontal ligament cells identifies activated states of MAP-kinases p42/44 and p38-stress kinase as a mechanism for MMP-13 expression. BMC Cell Biol. 2010; 11:10. [PubMed: 20109185]

27. Oortgiesen DA, Yu N, Bronckers AL, Yang F, Walboomers XF, Jansen JA. A three-dimensional cell culture model to study the mechano-biological behavior in periodontal ligament regeneration. Tissue Eng Part C Methods. 2012; 18:81-9. [PubMed: 21913838]

28. Riehl BD, Park JH, Kwon IK, Lim JY. Mechanical stretching for tissue engineering: twodimensional and three-dimensional constructs. Tissue Eng Part B Rev. 2012; 18:288-300. [PubMed: 22335794]

29. Kaku M, Uoshima K, Yamashita Y, Miura H. Investigation of periodontal ligament reaction upon excessive occlusal load--osteopontin induction among periodontal ligament cells. Journal of periodontal research. 2005; 40:59-66. [PubMed: 15613081]

30. Yoshinaga Y, Ukai T, Abe Y, Hara Y. Expression of receptor activator of nuclear factor kappa B ligand relates to inflammatory bone resorption, with or without occlusal trauma, in rats. Journal of periodontal research. 2007; 42:402-9. [PubMed: 17760817]

31. Sodeyama T, Maeda T, Takano Y, Hara K. Responses of periodontal nerve terminals to experimentally induced occlusal trauma in rat molars: an immunohistochemical study using PGP 9.5 antibody. Journal of periodontal research. 1996; 31:235-48. [PubMed: 8814593]

32. Kvinnsland S, Kristiansen AB, Kvinnsland I, Heyeraas KJ. Effect of experimental traumatic occlusion on periodontal and pulpal blood flow. Acta Odontol Scand. 1992; 50:211-9. [PubMed: 1514395]

33. Nozaki K, Kaku M, Yamashita Y, Yamauchi M, Miura H. Effect of cyclic mechanical loading on osteoclast recruitment in periodontal tissue. Journal of periodontal research. 2010; 45:8-15. [PubMed: 19602121]

34. Waldo CM, Rothblatt JM. Histologic response to tooth movement in the laboratory rat; procedure and preliminary observations. J Dent Res. 1954; 33:481-6. [PubMed: 13184036]

35. Ren Y, Maltha JC, Kuijpers-Jagtman AM. The rat as a model for orthodontic tooth movement--a critical review and a proposed solution. Eur J Orthod. 2004; 26:483-90. [PubMed: 15536836]

36. Butler WT, Birkedal-Hansen H, Beegle WF, Taylor RE, Chung E. Proteins of the periodontium. Identification of collagens with the [alpha1(I)]2alpha2 and [alpha1(III)]3 structures in bovine periodontal ligament. The Journal of biological chemistry. 1975; 250:8907-12. [PubMed: 1194268]

37. Yamauchi M, Katz EP, Mechanic GL. Intermolecular cross-linking and stereospecific molecular packing in type I collagen fibrils of the periodontal ligament. Biochemistry. 1986; 25:4907-13. [PubMed: 3768322] 
38. Bumann A, Carvalho RS, Schwarzer CL, Yen EH. Collagen synthesis from human PDL cells following orthodontic tooth movement. Eur J Orthod. 1997; 19:29-37. [PubMed: 9071043]

39. Karimbux NY, Rosenblum ND, Nishimura I. Site-specific Expression of Collagen I and XII mRNAs in the Rat Periodontal Ligament at Two Developmental Stages. Journal of Dental Research. 1992; 71:1355-62. [PubMed: 1629450]

40. Wescott DC, Pinkerton MN, Gaffey BJ, Beggs KT, Milne TJ, Meikle MC. Osteogenic gene expression by human periodontal ligament cells under cyclic tension. J Dent Res. 2007; 86:12126. [PubMed: 18037658]

41. Nishida E, Sasaki T, Ishikawa SK, et al. Transcriptome database KK-Periome for periodontal ligament development: expression profiles of the extracellular matrix genes. Gene. 2007; 404:709. [PubMed: 17928168]

42. Myllyharju J, Kivirikko KI. Collagens, modifying enzymes and their mutations in humans, flies and worms. Trends Genet. 2004; 20:33-43. [PubMed: 14698617]

43. Berkovitz BKB. The Periodontal Ligament In Health and Disease. Mosby (2nd). 1995

44. Barczyk M, Bolstad AI, Gullberg D. Role of integrins in the periodontal ligament: organizers and facilitators. Periodontol 2000. 2013; 63:29-47. [PubMed: 23931052]

45. Yamauchi, M. Collagen biochemistry: an overview. Vol. 6. World Scientific Publishing; 2002.

46. Trackman PC. Diverse biological functions of extracellular collagen processing enzymes. Journal of cellular biochemistry. 2005; 96:927-37. [PubMed: 16167328]

47. Nagase H, Ghosh S. Epigenetics: differential DNA methylation in mammalian somatic tissues. The FEBS journal. 2008; 275:1617-23. [PubMed: 18331347]

48. Ohi T, Uehara Y, Takatsu M, Watanabe M, Ono T. Hypermethylation of CpGs in the promoter of the COL1A1 gene in the aged periodontal ligament. J Dent Res. 2006; 85:245-50. [PubMed: 16498072]

49. Takatsu M, Uyeno S, Komura J, Watanabe M, Ono T. Age-dependent alterations in mRNA level and promoter methylation of collagen alpha1(I) gene in human periodontal ligament. Mech Ageing Dev. 1999; 110:37-48. [PubMed: 10580690]

50. Arnsdorf EJ, Tummala P, Castillo AB, Zhang F, Jacobs CR. The epigenetic mechanism of mechanically induced osteogenic differentiation. J Biomech. 2010; 43:2881-6. [PubMed: 20728889]

51. Ozaki S, Kaneko S, Podyma-Inoue KA, Yanagishita M, Soma K. Modulation of extracellular matrix synthesis and alkaline phosphatase activity of periodontal ligament cells by mechanical stress. Journal of periodontal research. 2005; 40:110-7. [PubMed: 15733145]

52. Saminathan A, Vinoth KJ, Wescott DC, et al. The effect of cyclic mechanical strain on the expression of adhesion-related genes by periodontal ligament cells in two-dimensional culture. Journal of periodontal research. 2012; 47:212-21. [PubMed: 22010885]

53. Hong HH, Pischon N, Santana RB, et al. A role for lysyl oxidase regulation in the control of normal collagen deposition in differentiating osteoblast cultures. J Cell Physiol. 2004; 200:53-62. [PubMed: 15137057]

54. Bentovim L, Amarilio R, Zelzer E. HIF1alpha is a central regulator of collagen hydroxylation and secretion under hypoxia during bone development. Development. 2012; 139:4473-83. [PubMed: 23095889]

55. Ishikawa Y, Wirz J, Vranka JA, Nagata K, Bächinger HP. Biochemical Characterization of the Prolyl 3-Hydroxylase 1 Cartilage-associated Protein Cyclophilin B Complex. Journal of Biological Chemistry. 2009; 284:17641-7. [PubMed: 19419969]

56. Weis MA, Hudson DM, Kim L, Scott M, Wu J-J, Eyre DR. Location of 3-Hydroxyproline Residues in Collagen Types I, II, III, and V/XI Implies a Role in Fibril Supramolecular Assembly. Journal of Biological Chemistry. 2010; 285:2580-90. [PubMed: 19940144]

57. Ishikawa Y, Bachinger HP. A molecular ensemble in the rER for procollagen maturation. Biochimica et biophysica acta. 2013; 1833:2479-91. [PubMed: 23602968]

58. Cabral WA, Perdivara I, Weis M, et al. Abnormal Type I Collagen Post-translational Modification and Crosslinking in a Cyclophilin B KO Mouse Model of Recessive Osteogenesis Imperfecta. PLoS Genet. 2014; 10:e1004465. [PubMed: 24968150] 
59. Oikarinen KS, Seppa ST. Effect of preservation media on proliferation and collagen biosynthesis of periodontal ligament fibroblasts. Endod Dent Traumatol. 1987; 3:95-9. [PubMed: 3476304]

60. Kivirikko KI, Myllyla R. Posttranslational enzymes in the biosynthesis of collagen: intracellular enzymes. Methods in enzymology. 1982; 82:245-304. Pt A. [PubMed: 6210830]

61. Yeowell HN, Walker LC. Tissue specificity of a new splice form of the human lysyl hydroxylase 2 gene. Matrix Biol. 1999; 18:179-87. [PubMed: 10372558]

62. Uzawa K, Grzesik WJ, Nishiura T, et al. Differential Expression of Human Lysyl Hydroxylase Genes, Lysine Hydroxylation, and Cross-Linking of Type I Collagen During Osteoblastic Differentiation In Vitro. Journal of Bone and Mineral Research. 1999; 14:1272-80. [PubMed: 10457259]

63. Mercer DK, Nicol PF, Kimbembe C, Robins SP. Identification, expression, and tissue distribution of the three rat lysyl hydroxylase isoforms. Biochemical and biophysical research communications. 2003; 307:803-9. [PubMed: 12878181]

64. van der Slot AJ, Zuurmond AM, Bardoel AF, et al. Identification of PLOD2 as telopeptide lysyl hydroxylase, an important enzyme in fibrosis. The Journal of biological chemistry. 2003; 278:40967-72. [PubMed: 12881513]

65. Myllyla R, Wang C, Heikkinen J, et al. Expanding the lysyl hydroxylase toolbox: new insights into the localization and activities of lysyl hydroxylase 3 (LH3). J Cell Physiol. 2007; 212:323-9. [PubMed: 17516569]

66. Kaku M, Mochida Y, Atsawasuwan P, Parisuthiman D, Yamauchi M. Post-translational modifications of collagen upon BMP-induced osteoblast differentiation. Biochemical and biophysical research communications. 2007; 359:463-8. [PubMed: 17553463]

67. Nagaoka H, Mochida Y, Atsawasuwan P, Kaku M, Kondoh T, Yamauchi M. 1,25(OH)2D3 regulates collagen quality in an osteoblastic cell culture system. Biochemical and biophysical research communications. 2008; 377:674-8. [PubMed: 18930711]

68. Shiiba M, Arnaud SB, Tanzawa H, Uzawa K, Yamauchi M. Alterations of collagen matrix in weight-bearing bones during skeletal unloading. Connect Tissue Res. 2001; 42:303-11. [PubMed: 11913774]

69. Saito M, Soshi S, Fujii K. Effect of hyper- and microgravity on collagen post-translational controls of MC3T3-E1 osteoblasts. J Bone Miner Res. 2003; 18:1695-705. [PubMed: 12968680]

70. de Araujo RM, Oba Y, Moriyama K. Identification of genes related to mechanical stress in human periodontal ligament cells using microarray analysis. Journal of periodontal research. 2007; 42:1522. [PubMed: 17214635]

71. Bank RA, Robins SP, Wijmenga C, et al. Defective collagen crosslinking in bone, but not in ligament or cartilage, in Bruck syndrome: indications for a bone-specific telopeptide lysyl hydroxylase on chromosome 17. Proceedings of the National Academy of Sciences of the United States of America. 1999; 96:1054-8. [PubMed: 9927692]

72. Nagai N, Hosokawa M, Itohara S, et al. Embryonic lethality of molecular chaperone hsp47 knockout mice is associated with defects in collagen biosynthesis. J Cell Biol. 2000; 150:1499506. [PubMed: 10995453]

73. Tasab M, Batten MR, Bulleid NJ. Hsp47: a molecular chaperone that interacts with and stabilizes correctly-folded procollagen. EMBO J. 2000; 19:2204-11. [PubMed: 10811611]

74. Ishida Y, Nagata K. Hsp47 as a collagen-specific molecular chaperone. Methods in enzymology. 2011; 499:167-82. [PubMed: 21683254]

75. Ishida Y, Kubota H, Yamamoto A, Kitamura A, Bachinger HP, Nagata K. Type I collagen in Hsp47-null cells is aggregated in endoplasmic reticulum and deficient in N-propeptide processing and fibrillogenesis. Mol Biol Cell. 2006; 17:2346-55. [PubMed: 16525016]

76. Oguro A, Sakurai T, Fujita Y, et al. The molecular chaperone HSP47 rapidly senses gravitational changes in myoblasts. Genes Cells. 2006; 11:1253-65. [PubMed: 17054723]

77. Pan H, Halper J. Regulation of heat shock protein 47 and type I procollagen expression in avian tendon cells. Cell Tissue Res. 2003; 311:373-82. [PubMed: 12658445]

78. Martinek N, Shahab J, Sodek J, Ringuette M. Is SPARC an Evolutionarily Conserved Collagen Chaperone? Journal of Dental Research. 2007; 86:296-305. [PubMed: 17384023] 
79. Trombetta JM, Bradshaw AD. SPARC/osteonectin functions to maintain homeostasis of the collagenous extracellular matrix in the periodontal ligament. J Histochem Cytochem. 2010:588719.

80. Chlenski A, Guerrero LJ, Salwen HR, et al. Secreted protein acidic and rich in cysteine is a matrix scavenger chaperone. PLoS One. 2011; 6:e23880. [PubMed: 21949685]

81. Martinek N, Shahab J, Sodek J, Ringuette M. Is SPARC an evolutionarily conserved collagen chaperone? J Dent Res. 2007; 86:296-305. [PubMed: 17384023]

82. Kudo H, Hirayoshi K, Kitagawa Y, Imamura S, Nagata K. Two collagen-binding proteins, osteonectin and HSP47, are coordinately induced in transformed keratinocytes by heat and other stresses. Exp Cell Res. 1994; 212:219-24. [PubMed: 8187816]

83. Schegg B, Hulsmeier AJ, Rutschmann C, Maag C, Hennet T. Core glycosylation of collagen is initiated by two beta(1-O)galactosyltransferases. Molecular and cellular biology. 2009; 29:943-52. [PubMed: 19075007]

84. Batge B, Winter C, Notbohm H, Acil Y, Brinckmann J, Muller PK. Glycosylation of human bone collagen I in relation to lysylhydroxylation and fibril diameter. J Biochem. 1997; 122:109-15. [PubMed: 9276678]

85. Torre-Blanco A, Adachi E, Hojima Y, Wootton JA, Minor RR, Prockop DJ. Temperature-induced post-translational over-modification of type I procollagen. Effects of over-modification of the protein on the rate of cleavage by procollagen $\mathrm{N}$-proteinase and on self-assembly of collagen into fibrils. The Journal of biological chemistry. 1992; 267:2650-5. [PubMed: 1733961]

86. Notbohm H, Nokelainen M, Myllyharju J, Fietzek PP, Muller PK, Kivirikko KI. Recombinant human type II collagens with low and high levels of hydroxylysine and its glycosylated forms show marked differences in fibrillogenesis in vitro. The Journal of biological chemistry. 1999; 274:8988-92. [PubMed: 10085145]

87. Amudeswari S, Liang JN, Chakrabarti B. Polar-apolar characteristics and fibrillogenesis of glycosylated collagen. Coll Relat Res. 1987; 7:215-23. [PubMed: 3652661]

88. Eyre DR, Glimcher MJ. Analysis of a crosslinked peptide from calf bone collagen: evidence that hydroxylysyl glycoside participates in the crosslink. Biochemical and biophysical research communications. 1973; 52:663-71. [PubMed: 4351144]

89. Yamauchi M, Noyes C, Kuboki Y, Mechanic GL. Collagen structural microheterogeneity and a possible role for glycosylated hydroxylysine in type I collagen. Proceedings of the National Academy of Sciences of the United States of America. 1982; 79:7684-8. [PubMed: 6961443]

90. Vogel W, Gish GD, Alves F, Pawson T. The discoidin domain receptor tyrosine kinases are activated by collagen. Mol Cell. 1997; 1:13-23. [PubMed: 9659899]

91. Jurgensen HJ, Madsen DH, Ingvarsen S, et al. A novel functional role of collagen glycosylation: interaction with the endocytic collagen receptor uparap/ENDO180. The Journal of biological chemistry. 2011; 286:32736-48. [PubMed: 21768090]

92. Tenni R, Valli M, Rossi A, Cetta G. Possible role of overglycosylation in the type I collagen triple helical domain in the molecular pathogenesis of osteogenesis imperfecta. Am J Med Genet. 1993; 45:252-6. [PubMed: 8456811]

93. Brenner RE, Vetter U, Nerlich A, Worsdorfer O, Teller WM, Muller PK. Altered collagen metabolism in osteogenesis imperfecta fibroblasts: a study on 33 patients with diverse forms. Eur J Clin Invest. 1990; 20:8-14. [PubMed: 2108039]

94. Cetta G, De Luca G, Tenni R, Zanaboni G, Lenzi L, Castellani AA. Biochemical investigations of different forms of osteogenesis imperfecta. Evaluation of 44 cases. Connect Tissue Res. 1983; 11:103-11.

95. Michalsky M, Norris-Suarez K, Bettica P, Pecile A, Moro L. Rat cortical and trabecular bone collagen glycosylation are differently influenced by ovariectomy. Biochemical and biophysical research communications. 1993; 192:1281-8. [PubMed: 8507198]

96. Moro L, Bettica P, Romanello M, Suarez KN. 17 beta-Estradiol and tamoxifen prevent the overglycosylation of rat trabecular bone collagen induced by ovariectomy. Eur J Clin Chem Clin Biochem. 1997; 35:29-33. [PubMed: 9156563] 
97. Lehmann HW, Wolf E, Roser K, Bodo M, Delling G, Muller PK. Composition and posttranslational modification of individual collagen chains from osteosarcomas and osteofibrous dysplasias. J Cancer Res Clin Oncol. 1995; 121:413-8. [PubMed: 7635871]

98. Otsubo K, Katz EP, Mechanic GL, Yamauchi M. Cross-linking connectivity in bone collagen fibrils: the carboxy-terminal locus of free aldehyde. Biochemistry. 1992; 31:396-402. [PubMed: 1731897]

99. Yamauchi M, Katz EP, Otsubo K, Teraoka K, Mechanic GL. Cross-linking and stereospecific structure of collagen in mineralized and nonmineralized skeletal tissues. Connect Tissue Res. 1989; 21:159-67. discussion 68-9. [PubMed: 2605940]

100. Terajima M, Perdivara I, Sricholpech M, et al. Glycosylation and cross-linking in bone type I collagen. The Journal of biological chemistry. 2014

101. Lucero HA, Kagan HM. Lysyl oxidase: an oxidative enzyme and effector of cell function. Cell Mol Life Sci. 2006; 63:2304-16. [PubMed: 16909208]

102. Atsawasuwan P, Mochida Y, Katafuchi M, et al. Lysyl oxidase binds transforming growth factorbeta and regulates its signaling via amine oxidase activity. The Journal of biological chemistry. 2008; 283:34229-40. [PubMed: 18835815]

103. Bing Z, Linlin L, Jianguo Y, Shenshen R, Ruifang R, Xi Z. Effect of mechanical stretch on the expressions of elastin, LOX and Fibulin-5 in rat BMSCs with ligament fibroblasts co-culture. Mol Biol Rep. 2012; 39:6077-85. [PubMed: 22205540]

104. Lambert CA, Colige AC, Lapiere CM, Nusgens BV. Coordinated regulation of procollagens I and III and their post-translational enzymes by dissipation of mechanical tension in human dermal fibroblasts. Eur J Cell Biol. 2001; 80:479-85. [PubMed: 11499790]

105. Uzel MI, Scott IC, Babakhanlou-Chase H, et al. Multiple bone morphogenetic protein 1-related mammalian metalloproteinases process pro-lysyl oxidase at the correct physiological site and control lysyl oxidase activation in mouse embryo fibroblast cultures. The Journal of biological chemistry. 2001; 276:22537-43. [PubMed: 11313359]

106. Horiuchi K, Amizuka N, Takeshita S, et al. Identification and characterization of a novel protein, periostin, with restricted expression to periosteum and periodontal ligament and increased expression by transforming growth factor beta. J Bone Miner Res. 1999; 14:1239-49. [PubMed: 10404027]

107. Maruhashi T, Kii I, Saito M, Kudo A. Interaction between periostin and BMP-1 promotes proteolytic activation of lysyl oxidase. The Journal of biological chemistry. 2010; 285:13294303. [PubMed: 20181949]

108. Rios HF, Ma D, Xie Y, et al. Periostin is essential for the integrity and function of the periodontal ligament during occlusal loading in mice. Journal of periodontology. 2008; 79:1480-90. [PubMed: 18672999]

109. Lv S, Liu H, Cui J, et al. Histochemical examination of cathepsin K, MMP1 and MMP2 in compressed periodontal ligament during orthodontic tooth movement in periostin deficient mice. J Mol Histol. 2014; 45:303-9. [PubMed: 24202437]

110. Tabata C, Hongo H, Sasaki M, et al. Altered distribution of extracellular matrix proteins in the periodontal ligament of periostin-deficient mice. Histol Histopathol. 2014; 29:731-42. [PubMed: 24352874]

111. Eyre DR, Paz MA, Gallop PM. Cross-Linking in Collagen and Elastin. Annual Review of Biochemistry. 1984; 53:717-48.

112. Eyre DR, Weis MA, Wu JJ. Advances in collagen cross-link analysis. Methods. 2008; 45:65-74. [PubMed: 18442706]

113. Plecash JM, Bentley JP. Crosslink analysis as an indicator of collagen turnover in periodontal ligament from functioning and non-functioning teeth in the dog. Arch Oral Biol. 1982; 27:463-8. [PubMed: 6956258]

114. Pearson CH, Wohllebe M, Carmichael DJ, Chovelon A. Bovine periodontal ligament. An invesitation of the collagen, glycosaminoglycan and insoluble glycoprotein components at different stages of tissue development. Connect Tissue Res. 1975; 3:195-206. [PubMed: 126133] 
115. Fleischmajer R, Olsen BR, Timpl R, Perlish JS, Lovelace O. Collagen fibril formation during embryogenesis. Proceedings of the National Academy of Sciences of the United States of America. 1983; 80:3354-8. [PubMed: 6574488]

116. Liu X, Wu H, Byrne M, Krane S, Jaenisch R. Type III collagen is crucial for collagen I fibrillogenesis and for normal cardiovascular development. Proceedings of the National Academy of Sciences of the United States of America. 1997; 94:1852-6. [PubMed: 9050868]

117. Pope FM, Martin GR, Lichtenstein JR, et al. Patients with Ehlers-Danlos syndrome type IV lack type III collagen. Proceedings of the National Academy of Sciences of the United States of America. 1975; 72:1314-6. [PubMed: 1055406]

118. Li J, Chen J, Kirsner R. Pathophysiology of acute wound healing. Clin Dermatol. 2007; 25:9-18. [PubMed: 17276196]

119. Liu SH, Panossian V, al-Shaikh R, et al. Morphology and matrix composition during early tendon to bone healing. Clin Orthop Relat Res. 1997:253-60. [PubMed: 9186227]

120. Kanazawa T, Soejima T, Murakami H, Inoue T, Katouda M, Nagata K. An immunohistological study of the integration at the bone-tendon interface after reconstruction of the anterior cruciate ligament in rabbits. J Bone Joint Surg Br. 2006; 88:682-7. [PubMed: 16645121]

121. Tabuchi K, Soejima T, Kanazawa T, Noguchi K, Nagata K. Chronological changes in the collagen-type composition at tendon-bone interface in rabbits. Bone Joint Res. 2012; 1:218-24. [PubMed: 23610694]

122. Juncosa-Melvin N, Matlin KS, Holdcraft RW, Nirmalanandhan VS, Butler DL. Mechanical stimulation increases collagen type I and collagen type III gene expression of stem cell-collagen sponge constructs for patellar tendon repair. Tissue Eng. 2007; 13:1219-26. [PubMed: 17518715]

123. Kim SG, Akaike T, Sasagaw T, Atomi Y, Kurosawa H. Gene expression of type I and type III collagen by mechanical stretch in anterior cruciate ligament cells. Cell Struct Funct. 2002; 27:139-44. [PubMed: 12207044]

124. Hsieh AH, Tsai CM, Ma QJ, et al. Time-dependent increases in type-III collagen gene expression in medical collateral ligament fibroblasts under cyclic strains. J Orthop Res. 2000; 18:220-7. [PubMed: 10815822]

125. Yamauchi M, Kuboki Y, Sasaki S, Mechanic GL. New pepsin-solubilized low molecular weight collagenous component possibly unique to periodontal ligament. Biochemistry. 1986; 25:19972002. [PubMed: 3011074]

126. MacNeil RL, Berry JE, Strayhorn CL, Shigeyama Y, Somerman MJ. Expression of type I and XII collagen during development of the periodontal ligament in the mouse. Arch Oral Biol. 1998; 43:779-87. [PubMed: 9796779]

127. Keene DR, Sakai LY, Burgeson RE. Human Bone Contains Type-Iii Collagen, Type-Vi Collagen, and Fibrillin - Type-Iii Collagen Is Present on Specific Fibers That May Mediate Attachment of Tendons, Ligaments, and Periosteum to Calcified Bone Cortex. Journal of Histochemistry \& Cytochemistry. 1991; 39:59-69. [PubMed: 1983874]

128. Font B, Eichenberger D, Rosenberg LM, van der Rest M. Characterization of the interactions of type XII collagen with two small proteoglycans from fetal bovine tendon, decorin and fibromodulin. Matrix Biol. 1996; 15:341-8. [PubMed: 8981330]

129. Veit G, Hansen U, Keene DR, et al. Collagen XII interacts with avian tenascin-X through its NC3 domain. The Journal of biological chemistry. 2006; 281:27461-70. [PubMed: 16861231]

130. Oh SP, Griffith CM, Hay ED, Olsen BR. Tissue-specific expression of type XII collagen during mouse embryonic development. Dev Dyn. 1993; 196:37-46. [PubMed: 8334298]

131. Gregory KE, Keene DR, Tufa SF, Lunstrum GP, Morris NP. Developmental distribution of collagen type XII in cartilage: association with articular cartilage and the growth plate. J Bone Miner Res. 2001; 16:2005-16. [PubMed: 11697796]

132. MacNeil RL, Berry JE, Strayhorn CL, Shigeyama Y, Somerman MJ. Expression of type I and XII collagen during development of the periodontal ligament in the mouse. Archives of Oral Biology. 1998; 43:779-87. [PubMed: 9796779] 
133. Tzortzaki EG, Tischfield JA, Sahota A, Siafakas NM, Gordon MK, Gerecke DR. Expression of FACIT collagens XII and XIV during bleomycin-induced pulmonary fibrosis in mice. Anat Rec A Discov Mol Cell Evol Biol. 2003; 275:1073-80. [PubMed: 14613307]

134. Karimbux NY, Rosenblum ND, Nishimura I. Site-specific expression of collagen I and XII mRNAs in the rat periodontal ligament at two developmental stages. J Dent Res. 1992; 71:135562. [PubMed: 1629450]

135. Reichenberger E, Baur S, Sukotjo C, Olsen BR, Karimbux NY, Nishimura I. Collagen XII mutation disrupts matrix structure of periodontal ligament and skin. J Dent Res. 2000; 79:19628. [PubMed: 11201046]

136. Yamagata M, Yamada KM, Yamada SS, et al. The complete primary structure of type XII collagen shows a chimeric molecule with reiterated fibronectin type III motifs, von Willebrand factor A motifs, a domain homologous to a noncollagenous region of type IX collagen, and short collagenous domains with an Arg-Gly-Asp site. J Cell Biol. 1991; 115:209-21. [PubMed: 1918137]

137. Lunstrum GP, McDonough AM, Marinkovich MP, Keene DR, Morris NP, Burgeson RE. Identification and partial purification of a large, variant form of type XII collagen. The Journal of biological chemistry. 1992; 267:20087-92. [PubMed: 1400326]

138. Karimbux NY, Nishimura I. Temporal and spatial expressions of type XII collagen in the remodeling periodontal ligament during experimental tooth movement. J Dent Res. 1995; 74:313-8. [PubMed: 7876423]

139. Nishiyama T, McDonough AM, Bruns RR, Burgeson RE. Type XII and XIV collagens mediate interactions between banded collagen fibers in vitro and may modulate extracellular matrix deformability. The Journal of biological chemistry. 1994; 269:28193-9. [PubMed: 7961756]

140. Fluck M, Giraud MN, Tunc V, Chiquet M. Tensile stress-dependent collagen XII and fibronectin production by fibroblasts requires separate pathways. Biochimica et biophysica acta. 2003; 1593:239-48. [PubMed: 12581868]

141. Keller KE, Kelley MJ, Acott TS. Extracellular matrix gene alternative splicing by trabecular meshwork cells in response to mechanical stretching. Invest Ophthalmol Vis Sci. 2007; 48:116472. [PubMed: 17325160]

142. Jin X, Iwasa S, Okada K, Ooi A, Mitsui K, Mitsumata M. Shear stress-induced collagen XII expression is associated with atherogenesis. Biochemical and biophysical research communications. 2003; 308:152-8. [PubMed: 12890494]

143. Arai K, Nagashima Y, Takemoto T, Nishiyama T. Mechanical strain increases expression of type XII collagen in murine osteoblastic MC3T3-E1 cells. Cell Struct Funct. 2008; 33:203-10. [PubMed: 18957791]

144. Chiquet M, Mumenthaler U, Wittwer M, Jin W, Koch M. The chick and human collagen alpha1(XII) gene promoter--activity of highly conserved regions around the first exon and in the first intron. Eur J Biochem. 1998; 257:362-71. [PubMed: 9826181]

145. Iozzo RV. The biology of the small leucine-rich proteoglycans. Functional network of interactive proteins. The Journal of biological chemistry. 1999; 274:18843-6. [PubMed: 10383378]

146. Chen S, Birk DE. The regulatory roles of small leucine-rich proteoglycans in extracellular matrix assembly. The FEBS journal. 2013; 280:2120-37. [PubMed: 23331954]

147. Leong NL, Hurng JM, Djomehri SI, Gansky SA, Ryder MI, Ho SP. Age-related adaptation of bone-PDL-tooth complex: Rattus-Norvegicus as a model system. PLoS One. 2012; 7:e35980. [PubMed: 22558292]

148. Matheson S, Larjava H, Hakkinen L. Distinctive localization and function for lumican, fibromodulin and decorin to regulate collagen fibril organization in periodontal tissues. Journal of periodontal research. 2005; 40:312-24. [PubMed: 15966909]

149. Juneja SC, Veillette C. Defects in tendon, ligament, and enthesis in response to genetic alterations in key proteoglycans and glycoproteins: a review. Arthritis. 2013; 2013:154812. [PubMed: 24324885]

150. Hakkinen L, Strassburger S, Kahari VM, et al. A role for decorin in the structural organization of periodontal ligament. Laboratory investigation; a journal of technical methods and pathology. 2000; 80:1869-80. 
151. Santra M, Mann DM, Mercer EW, Skorski T, Calabretta B, Iozzo RV. Ectopic expression of decorin protein core causes a generalized growth suppression in neoplastic cells of various histogenetic origin and requires endogenous p21, an inhibitor of cyclin-dependent kinases. J Clin Invest. 1997; 100:149-57. [PubMed: 9202067]

152. Liu M, Dai J, Lin Y, et al. Effect of the cyclic stretch on the expression of osteogenesis genes in human periodontal ligament cells. Gene. 2012; 491:187-93. [PubMed: 22019432]

153. Kalamajski S, Aspberg A, Lindblom K, Heinegard D, Oldberg A. Asporin competes with decorin for collagen binding, binds calcium and promotes osteoblast collagen mineralization. Biochem J. 2009; 423:53-9. [PubMed: 19589127]

154. Nakajima M, Kizawa H, Saitoh M, Kou I, Miyazono K, Ikegawa S. Mechanisms for asporin function and regulation in articular cartilage. The Journal of biological chemistry. 2007; 282:32185-92. [PubMed: 17827158]

155. Yamada S, Tomoeda M, Ozawa Y, et al. PLAP-1/asporin, a novel negative regulator of periodontal ligament mineralization. The Journal of biological chemistry. 2007; 282:23070-80. [PubMed: 17522060]

156. Yamauchi M, Shiiba M. Lysine hydroxylation and cross-linking of collagen. Methods Mol Biol. 2008; 446:95-108. [PubMed: 18373252]

157. Perdivara I, Yamauchi M, Tomer KB. Molecular Characterization of Collagen Hydroxylysine OGlycosylation by Mass Spectrometry: Current Status. Aust J Chem. 2013; 66:760-9. [PubMed: 25414518]

158. Komatsu K, Mosekilde L, Viidik A, Chiba M. Polarized light microscopic analyses of collagen fibers in the rat incisor periodontal ligament in relation to areas, regions, and ages. Anat Rec. 2002; 268:381-7. [PubMed: 12420286]

159. Paschalis EP, Verdelis K, Doty SB, Boskey AL, Mendelsohn R, Yamauchi M. Spectroscopic characterization of collagen cross-links in bone. J Bone Miner Res. 2001; 16:1821-8. [PubMed: 11585346]

160. Morris MD, Mandair GS. Raman assessment of bone quality. Clin Orthop Relat Res. 2011; 469:2160-9. [PubMed: 21116756]

161. Boskey A, Pleshko Camacho N. FT-IR imaging of native and tissue-engineered bone and cartilage. Biomaterials. 2007; 28:2465-78. [PubMed: 17175021]

162. d'Apuzzo F, Cappabianca S, Ciavarella D, Monsurro A, Silvestrini-Biavati A, Perillo L. Biomarkers of periodontal tissue remodeling during orthodontic tooth movement in mice and men: overview and clinical relevance. TheScientificWorldJournal. 2013; 2013:105873.

163. Wu J, Li Y, Fan X, Zhang C, Wang Y, Zhao Z. Analysis of gene expression profile of periodontal ligament cells subjected to cyclic compressive force. DNA Cell Biol. 2011; 30:865-73. [PubMed: 21510798]

164. Wang Y, Li Y, Fan X, Zhang Y, Wu J, Zhao Z. Early proliferation alteration and differential gene expression in human periodontal ligament cells subjected to cyclic tensile stress. Arch Oral Biol. 2011; 56:177-86. [PubMed: 20934684]

165. Pinkerton MN, Wescott DC, Gaffey BJ, Beggs KT, Milne TJ, Meikle MC. Cultured human periodontal ligament cells constitutively express multiple osteotropic cytokines and growth factors, several of which are responsive to mechanical deformation. Journal of periodontal research. 2008; 43:343-51. [PubMed: 18086169]

166. Ritter N, Mussig E, Steinberg T, Kohl A, Komposch G, Tomakidi P. Elevated expression of genes assigned to NF-kappaB and apoptotic pathways in human periodontal ligament fibroblasts following mechanical stretch. Cell Tissue Res. 2007; 328:537-48. [PubMed: 17340152]

167. Lee YH, Nahm DS, Jung YK, et al. Differential gene expression of periodontal ligament cells after loading of static compressive force. Journal of periodontology. 2007; 78:446-52. [PubMed: 17335367]

168. Ku SJ, Chang YI, Chae $\mathrm{CH}$, et al. Static tensional forces increase osteogenic gene expression in three-dimensional periodontal ligament cell culture. BMB Rep. 2009; 42:427-32. [PubMed: 19643040]

169. McCulloch CA, Bordin S. Role of fibroblast subpopulations in periodontal physiology and pathology. Journal of periodontal research. 1991; 26:144-54. [PubMed: 1830616] 
170. Chen SC, Marino V, Gronthos S, Bartold PM. Location of putative stem cells in human periodontal ligament. Journal of periodontal research. 2006; 41:547-53. [PubMed: 17076780]

171. Seo BM, Miura M, Gronthos S, et al. Investigation of multipotent postnatal stem cells from human periodontal ligament. Lancet. 2004; 364:149-55. [PubMed: 15246727]

172. Guilak F, Cohen DM, Estes BT, Gimble JM, Liedtke W, Chen CS. Control of stem cell fate by physical interactions with the extracellular matrix. Cell stem cell. 2009; 5:17-26. [PubMed: 19570510]

173. Engler AJ, Sen S, Sweeney HL, Discher DE. Matrix elasticity directs stem cell lineage specification. Cell. 2006; 126:677-89. [PubMed: 16923388]

174. Shimonishi M, Sato J, Takahashi N, Komatsu M. Expression of type IV collagen and laminin at the interface between epithelial cells and fibroblasts from human periodontal ligament. Eur J Oral Sci. 2005; 113:34-40. [PubMed: 15693827]

175. Lukinmaa PL, Waltimo J. Immunohistochemical localization of types I, V, and VI collagen in human permanent teeth and periodontal ligament. J Dent Res. 1992; 71:391-7. [PubMed: 1556297]

176. Yoshimatsu M, Uehara M, Yoshida N. Expression of heat shock protein 47 in the periodontal ligament during orthodontic tooth movement. Arch Oral Biol. 2008; 53:890-5. [PubMed: 18359004]

177. Ozer A, Yuan G, Yang G, et al. Domain of dentine sialoprotein mediates proliferation and differentiation of human periodontal ligament stem cells. PLoS One. 2013; 8:e81655. [PubMed: 24400037]

178. Jung IH, Park JC, Kim JC, et al. Novel application of human periodontal ligament stem cells and water-soluble chitin for collagen tissue regeneration: in vitro and in vivo investigations. Tissue Eng Part A. 2012; 18:643-53. [PubMed: 21981356] 


\section{Collagen Biosynthesis}

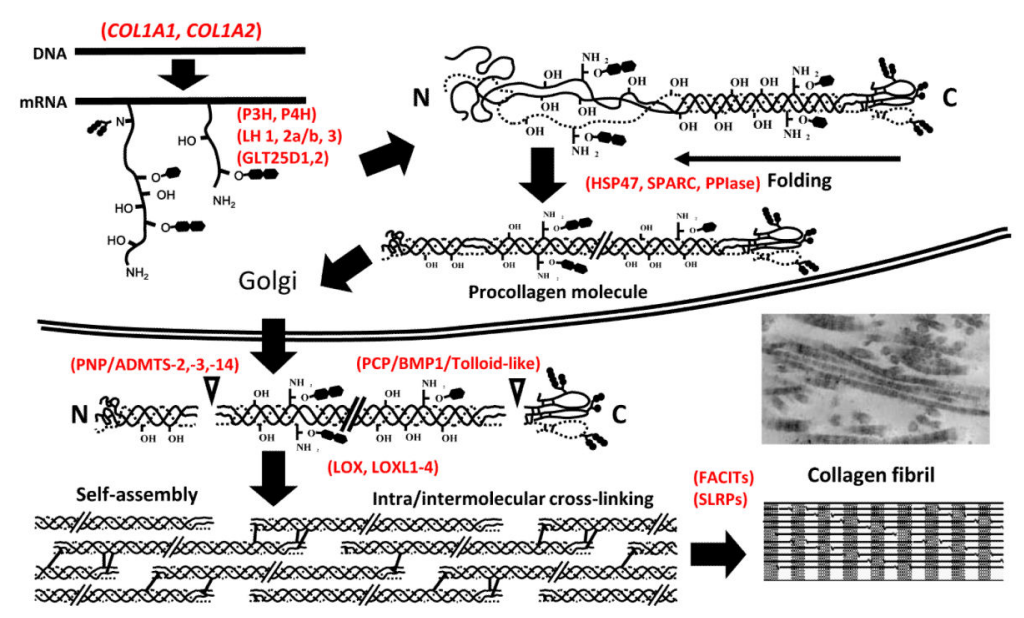

Fig. 1. Schematic image of biosynthesis of type I collagen

A series of collagen-modifying enzymes, molecular chaperones and associated molecules participate in the normal secretion and proper function of type I collagen. After or during the translation of a-chains of type I collagen, specific proline and lysine residues are hydroxylated by PHs and LHs, respectively. Following the hydroxylation of lysine residue, GLT25D serves as a GT and LH3 serves as a GGT. HSP47 and SPARC facilitate the folding of three a-chains into triple helical structures as molecular chaperones. The triple helical procollagen molecules are secreted to the extracellular space and then both $\mathrm{N}$ - and C-ends are cleaved by PNP and PCP to form mature type I collagen. LOX catalyzes aldehyde formation in the telopeptide domains of mature type I collagen. These aldehydes spontaneously react with other aldehydes or unmodified lysine and hydroxylysine residues to form various intra- and intermolecular cross-links. The FACITs and SLRPs bind to the surface of type I collagen fibrils and regulate fibrillar growth. PH, Prolyl hydroxylase; LH, Lysyl hydroxylase; GT, Hydroxylysine galactosyl transferase; GGT, Galactosylhydroxylysine-glucosyl transferase; PPIase, Peptidylprolylisomerase; PNP, Procollagen N proteinase; PCP, Procollagen C proteinase; LOX, Lysyl oxidase; FACITs, Fibril associated collagens with interrupted triple helices; SLRPs, Small leucine-rich proteoglycans. See text for details. Modified from (Yamauchi, 2002)[45]. 


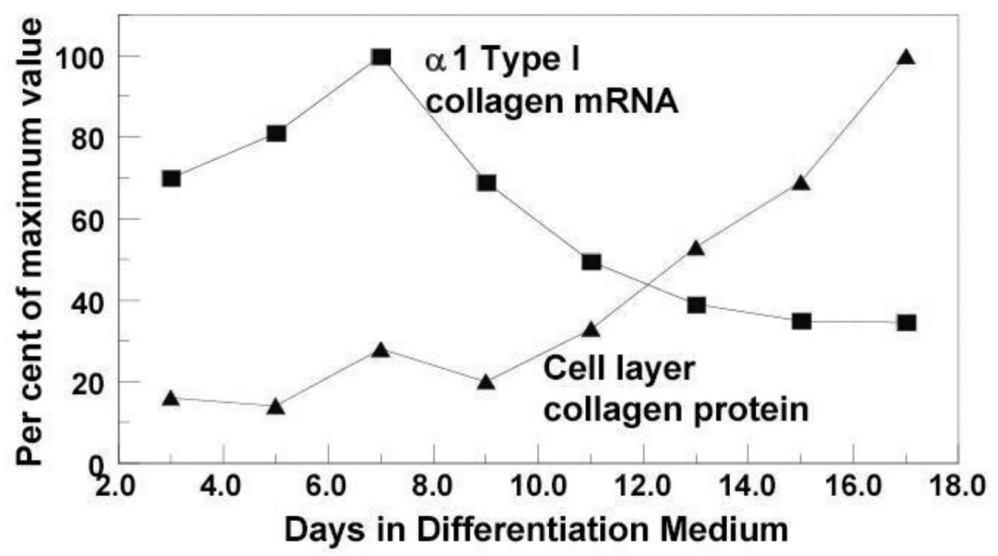

Fig. 2. Relationship between type I collagen mRNA and cell layer collagen protein accumulation MC3T3-E1 osteoblastic cell line was cultured in differentiation medium, and gene expression of Col1a1 and cell layer type I collagen contents were analyzed by Northern blot and amino acid analysis, respectively. Colla1 gene expression was highest at day 7 and decreased gradually thereafter, while extracellular collagen accumulation became evident after 9 days of culture. Such discrepancies occurs, in part, due to the complex biosynthesis process including post-translational modifications (shown in Fig.1) Modified from (Hong et al., 2004)[53]. 


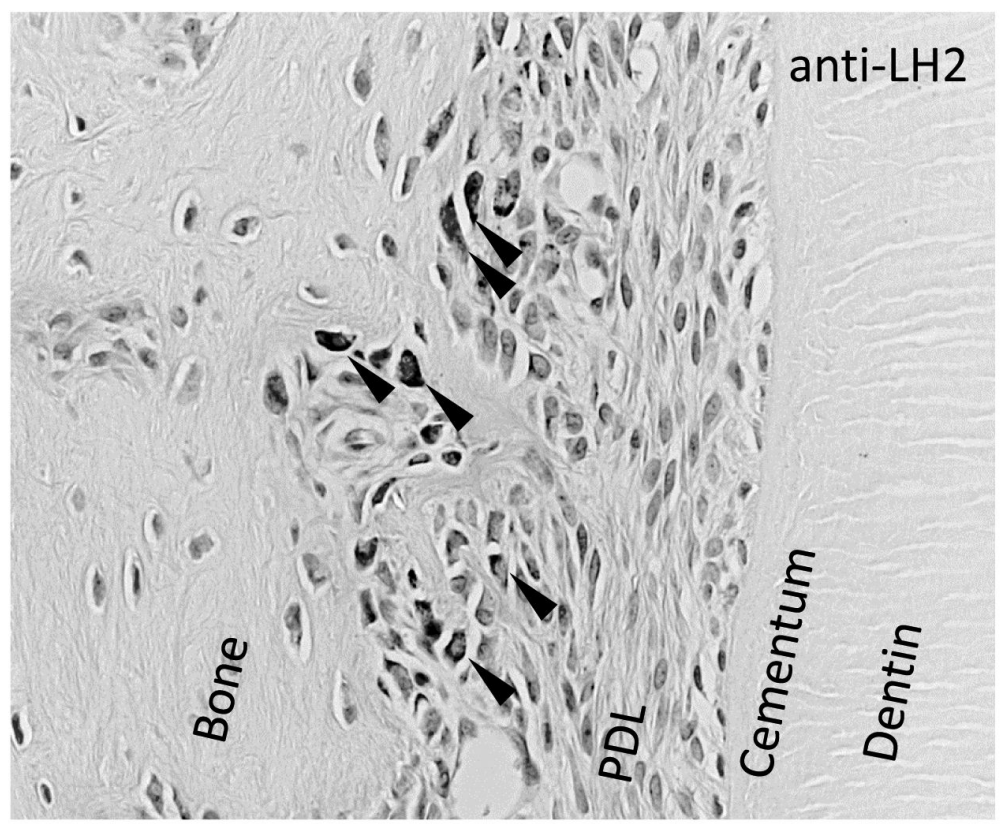

Fig. 3. Mechanical occlusal loading induces LH2 expression on alveolar bone side of PDL Eight-week-old male SD rats were subjected to 3 days of excessive occlusal loading (Kaku et al., 2005)[29]. Decalcified, paraffin embedded histology samples were prepared and the distribution of LH2 was analyzed by means of immunohistochemistry. Anti-LH2-positive cells were detected only at the bone side PDL in the experimental group (arrow heads). 


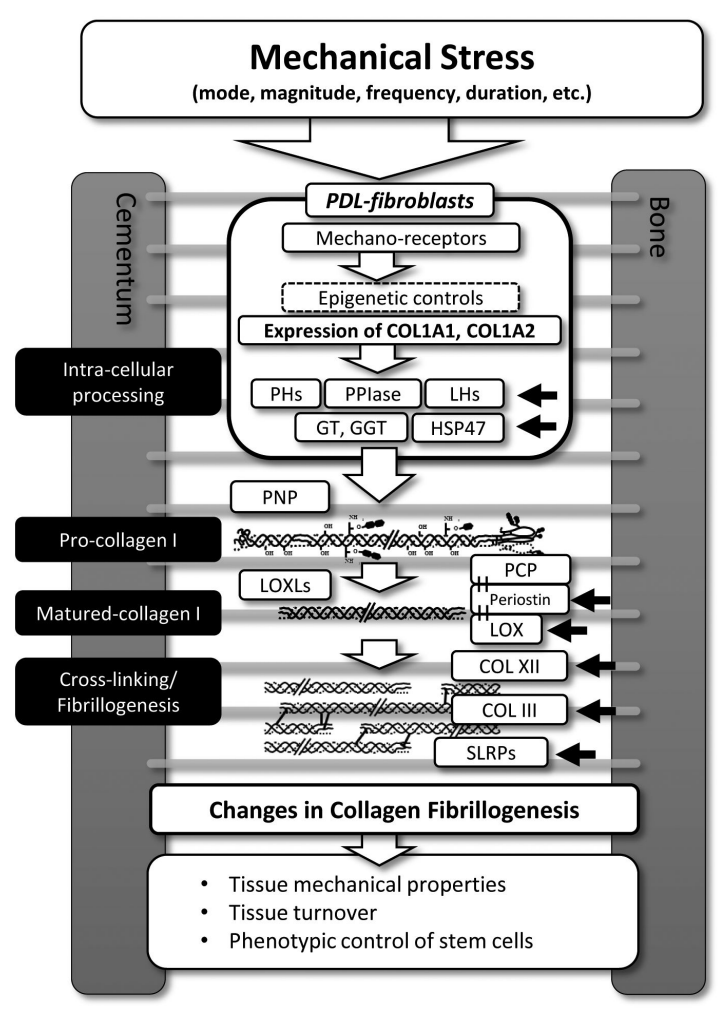

Fig. 4. Mechanical loadings affects the expression of type I collagen and its post-translational modifications in PDL at multiple steps

The collagen-modifying enzymes and -associated molecules which are crucial for collagen fibrillogenesis are summarized in this figure. Various factors of mechanical loading, such as mode, magnitude, frequency and duration, affect the response of PDL-fibroblasts. Black arrows indicate the known mechano-responsive collagen-related molecules in PDL. Other molecules could be affected by mechanical loading in PDL, but not have been tested. The changes in collagen fibrillogenesis exert influence on the tissue mechanical properties, tissue turnover and most likely phenotypic control of stem cells in PDL. PH, Prolyl hydroxylase; LH, Lysyl hydroxylase; GT, PPIase, Peptidylprolylisomerase; Hydroxylysine galactosyl transferase; GGT, Galactosylhydroxylysine-glucosyl transferase; PNP, Procollagen N proteinase; PCP, Procollagen C proteinase; LOX, Lysyl oxidase; SLRPs, Small leucine-rich proteoglycans. See main text for detail. 


\section{Table 1}

Collagens found in Periodontal Ligament

\begin{tabular}{|c|c|c|c|c|c|}
\hline Collagen & Form & Gene & $\begin{array}{l}\text { Human } \\
\text { disease }\end{array}$ & $\begin{array}{l}\text { Mechano-re } \\
\text { sponse }\end{array}$ & References \\
\hline Type I & Fibrillar & COL1A1, COL1A2 & $\begin{array}{l}\text { OI, } \\
\text { EDS type VIIA and VIIB }\end{array}$ & $\bigcirc$ & {$[38,138]$} \\
\hline Type II & Fibrillar & COL2A1 & $\begin{array}{l}\text { Chondrodysplasia, } \\
\text { Osteoarthrosis }\end{array}$ & $\bigcirc$ & {$[40]$} \\
\hline Type III & Fibrillar & COL3A1 & EDS type IV & $\bigcirc$ & {$[19,38,40]$} \\
\hline Type IV & $\begin{array}{l}\text { Basement } \\
\text { membrane }\end{array}$ & $\begin{array}{l}\text { COL4A1, COL4A2, } \\
\text { COL4A3, COL4A4, } \\
\text { COL4A5, COL4A6 }\end{array}$ & Alport syndrome & ND & {$[174]$} \\
\hline Type V & Fibrillar & $\begin{array}{l}\text { COL5A1, COL5A2, } \\
\text { COL5A3, COL5A4 }\end{array}$ & EDS type I and II & $\bigcirc$ & {$[38,175]$} \\
\hline Type VI & Beaded filament & $\begin{array}{l}\text { COL6A1, COL6A2, } \\
\text { COL6A3 }\end{array}$ & $\begin{array}{l}\text { Bethlem myopathy, } \\
\text { Ullrich muscular dystrophy }\end{array}$ & $\bigcirc$ & {$[38,175]$} \\
\hline Type XII & $\begin{array}{l}\text { FACIT } \\
\text { (PG) }\end{array}$ & COL12A1 & $\begin{array}{l}\text { Unknown, Disruption of } \\
\text { PDL in KO mice }\end{array}$ & $\bigcirc$ & {$[38,138]$} \\
\hline Type XI & Fibrillar & COL11A1, COL11A2 & $\begin{array}{l}\text { Chondrodysplasias } \\
\text { Osteoarthrosis }\end{array}$ & $\bigcirc$ & {$[40,41]$} \\
\hline Type XIV & $\begin{array}{l}\text { FACIT } \\
\text { (PG) }\end{array}$ & COL14A1 & Unknown & $\mathrm{ND}$ & {$[38]$} \\
\hline $\begin{array}{l}\text { Type XV } \\
\text { (EST-base) }\end{array}$ & $\begin{array}{l}\text { Basement } \\
\text { membrane } \\
(\mathrm{PG})\end{array}$ & COL15A1 & Unknown & ND & [41] \\
\hline $\begin{array}{l}\text { Type XVI } \\
\text { (EST-base) }\end{array}$ & FACIT & COL16A1 & Unknown & ND & {$[41]$} \\
\hline
\end{tabular}

UN; Unknown

ND; Not determined

PG; Proteoglycan

FACIT; Fibril associated collagens with interrupted triple helices

EST-base; Detected only in EST-base analysis

EDS; Ehlers-Danlos syndrome

OI; Osteogenesis imperfecta 
Table 2

Collagen-modifying enzymes and molecular chaperones in PDL

\begin{tabular}{|c|c|c|c|c|c|}
\hline $\begin{array}{l}\text { Protein name } \\
\text { (gene symbol) }\end{array}$ & Function & $\begin{array}{l}\text { Human } \\
\text { disease }\end{array}$ & $\begin{array}{l}\text { Expression } \\
\text { in PDL }\end{array}$ & $\begin{array}{l}\text { Mecliano- } \\
\text { response } \\
\text { in PDL }\end{array}$ & References \\
\hline Prolyl-4-hydroxylases & $\mathrm{PH}$ & UN & $\bigcirc$ & ND & [59] \\
\hline Prolyl-3-hydroxylase & $\mathrm{PH}$ & UN & ND & ND & \\
\hline LH1 (PLOD1) & LH & EDS type VIA & 0 & - & (Kaku, unpublished) \\
\hline LH2 (PLOD2) & LH & Bruck syndrome & 0 & $\bigcirc$ & [70](Kaku, unpublished) \\
\hline LH3 (PLOD3) & GGT & Connective tissue disorder & 0 & - & (Kaku, unpublished) \\
\hline GLT25D1 & GT & UN & ND & ND & \\
\hline GLT25D2 & GT & UN & ND & ND & \\
\hline HSP47 & $\begin{array}{l}\text { Molecular } \\
\text { chaperone }\end{array}$ & OI type $\mathrm{X}$ & $\bigcirc$ & $\bigcirc$ & [176] \\
\hline SPARC & $\begin{array}{l}\text { Molecular } \\
\text { chaperone }\end{array}$ & UN & $\bigcirc$ & ND & [79] \\
\hline Cyclophilin B (PPIB) & PPIase & OI type IX & ND & ND & \\
\hline FKBP65 (FKBP10) & PPIase & OI type XI, Bruck syndrome & ND & ND & \\
\hline FKBP22 (FKBP14) & PPIase & EDS type VIA and VIB & ND & ND & \\
\hline ADAMTS-2 & PNP & EDS type VIIC & ND & ND & \\
\hline ADAMTS-3 & PNP & UN & ND & ND & \\
\hline ADAMTS-14 & PNP & UN & ND & ND & \\
\hline BMP1/TLD & $\mathrm{PCP}$ & OI type XIII & 0 & ND & [177] \\
\hline LOX & LO & Lathyrism & 0 & $\bigcirc$ & {$[19,178]$} \\
\hline LOXL1 & LO & Exofoliation syndrome & $\bigcirc$ & ND & {$[178]$} \\
\hline LOXL2 & UN & $\mathrm{UN}$ & 0 & ND & [178] \\
\hline LOXL3 & UN & $\mathrm{UN}$ & ND & ND & \\
\hline LOXL4 & UN & UN & ND & ND & \\
\hline
\end{tabular}

PH; Prolyl hydroxylase

GT; Hydroxylysine galactosyl transferase

GGT; Galactosylhydroxylysine-glucosyl transferase

FKBP; FK506 binding protein

PNP; Procollagen N proteinase

LOX; Lysyl oxidase

OI; Osteogenesis imperfecta

UN; Unknown

LH; Lysyl hydroxylase

PPIase; Peptidylprolylisomerase

PCP; Procollagen C proteinase

EDS; Ehlers-Danlos syndrome

ND; Not determined 